\title{
STUDIES ON THE PHYSICAL ANTHROPOLOGY OF THE NETHERLANDS ANTILLES: II
}

\author{
INDIAN SKELETAL REMAINS FROM ARUBA
}

THE ORIGIN OF THE ARUBA INDIANS

The Leeward Group of the Netherlands Antilles, which comprises Aruba, Curaçao and Bonaire, is situated at $12^{\circ}$ latitude north, off the coast of Venezuela.

The Spaniards, who discovered these islands in I499, declared them to be 'useless' since no precious metals were found on them. As Hispaniola (Haiti) was in need of labourers, the Spanish viceroy of the territory, DIEGo Colón, ordered the transfer of the inhabitants of the islands to Haiti. The order was carried out in I5I5 (VAN GroL, I934). Approximately 2,000 Indians were transported from Aruba, Curaçao and Bonaire, and wherever possible the rest were killed. Round about I527, JUAn DE AMPUÉs, 'indiero pacífico' (GosLINGA, I957), returned part of the population to the islands. HARTOG (I953) mentions that DE AMPUÉs, aware of the difference between the peaceful Arawaks and the bellicose Caribs, only took back members of the former group. In I634 Curaçao was captured by the Dutch; the Spaniards on Aruba gradually withdrew, taking their Indian slaves with them, and the remaining Indians on Aruba retreated to Venezuela. After the Dutch occupation of Aruba in 1636, and its settlement by the first Dutch colonists, Aruba was populated again by Indians from the region west of Lake Maracaibo.

A general relationship seems to exist between the cultures of Aruba, Curaçao, Bonaire and the north-west coast of Venezuela (KIDDER, I944). With regard to rock paintings, this relationship was noticed as long ago as I89o by PINART, whose 'Aperçu sur l'île d'Aruba, ses habitants, ses antiquités, ses pétroglyphes' is reprinted in WAGENAAR HUMMELINCK's 1957 treatise on rock drawings found on Aruba. 